\title{
A simple method for estimating larval supply in reef fishes and a preliminary test of population limitation by larval delivery in the kelp bass Paralabrax clathratus
}

\author{
Mark A. Steele ${ }^{1, *}$, John C. Malone ${ }^{2}$, Amy M. Findlay ${ }^{3, * *}$, Mark H. Carr ${ }^{4}$, \\ Graham E. Forrester ${ }^{1}$ \\ ${ }^{1}$ Department of Biological Sciences, Biological Sciences Center, 100 Flagg Road, University of Rhode Island, \\ Kingston, Rhode Island 02881-0816, USA \\ ${ }^{2}$ Department of Organismic Biology, Ecology and Evolution, University of California Los Angeles, \\ 621 Charles E. Young Drive South, Los Angeles, California 90095-1606, USA \\ ${ }^{3}$ Department of Biology, California State University, Northridge, 18111 Nordhoff Street, Northridge, \\ California 91330-8303, USA \\ ${ }^{4}$ Department of Biology, University of California, Santa Cruz, California 95064, USA
}

\begin{abstract}
This paper describes a method for estimating larval supply of a temperate reef fish, the kelp bass Paralabrax clathratus, that is simple, inexpensive, requires relatively low effort, and integrates larval supply over time. Using this method, we sampled larval supply concurrently at 4 sites spread over about $35 \mathrm{~km}$ for nearly an entire settlement season. With these data and visual estimates of recruitment (the density of young-of-the-year after the end of the settlement season), we tested the hypothesis that spatial patterns in recruitment were set by larval supply. This hypothesis was rejected: kelp bass recruitment to the 4 sites was not related to patterns of larval supply. Furthermore, in contrast to the findings of an earlier study, recruitment was not related to the density of the macroalga Macrocystis pyrifera. Recruitment was, however, strongly correlated with the density of $1 \mathrm{yr}$ old kelp bass, suggesting that spatial patterns of recruitment were consistent between the 2 cohorts. Recruitment, however, was not correlated with the density of bass $2+$ yr old. We also measured larval supply in a second year and found that spatial patterns of supply were strongly correlated between years at a relatively small scale of $10 \mathrm{~s}$ to $100 \mathrm{~s} \mathrm{~m}$, but not at a larger scale of several $\mathrm{km}$. This finding suggests that some deterministic process (or set of processes) sets spatial patterns of larval supply at small, but not large scales. At large scales, consistent patterns of recruitment between 2 cohorts in the face of variable larval supply suggest that deterministic, postsettlement processes may generate predictable patterns of recruitment even when the supply of larvae is variable. In addition to demonstrating that spatial patterns in the abundance of demersal fish are not always well predicted by larval supply, this study introduces a technique that may facilitate more thorough exploration of the role of larval supply in determining the dynamics of populations of reef fishes.
\end{abstract}

KEY WORDS: Larval supply $\cdot$ Settlement $\cdot$ Recruitment $\cdot$ Reef fish $\cdot$ Population dynamics $\cdot$ Paralabrax clathratus

\section{INTRODUCTION}

${ }^{*}$ E-mail: steele@uri.edu

${ }^{* *}$ Present address: Community Environmental Council, Watershed Resource Center, 2981 Cliff Drive, Santa Barbara, California 93109, USA
The size of populations of benthic invertebrates and demersal fishes is set by the joint actions of larval supply, settlement processes, and postsettlement processes (reviewed in Olafsson et al. 1994, Caley et al. 
1996); yet, with few exceptions (e.g. Yoshioka 1982, Bertness et al. 1992, Eggleston \& Armstrong 1995), we have little understanding of the relative importance of these sets of processes. This is largely because it has been difficult to measure larval supply at meaningful spatial and temporal scales (Gaines \& Bertness 1993). Most methods used to quantify the rate at which larvae replenish benthic populations are labor intensive, subject to biases, and do not integrate larval supply over time. This problem is particularly acute in studies of reef fish, which have large, active larvae (Kaufman et al. 1992, Leis \& Carson-Ewart 1998) that are capable of avoiding capture by many methods (Choat et al. 1993).

Existing methods for measuring larval delivery in reef fishes have several limitations. A problem common to all methods is the difficulty of adequately integrating larval supply over time (Gaines \& Bertness 1993). For example, light traps only sample at night and often only for a few hours each night (e.g. Milicich et al. 1992, Doherty et al. 1996), towed nets and seines of various types (e.g. Choat et al. 1993, Hamer \& Jenkins 1996) provide only snapshots of larval abundance, and moored nets (e.g. Keener et al. 1988, Shenker et al. 1993) sample only when and where there is sufficient current to force larvae into them. Because larval supply is thought to be extremely variable over time, methods that are unable to sample continuously may fail to provide accurate estimates of the actual rate of larval delivery (Gaines \& Bertness 1993), which makes it difficult to quantify the influence of larval supply on spatial patterns and dynamics of benthic and demersal populations. A further problem is that all methods commonly used for measuring larval supply in reef fishes, such as light traps, towed nets, and moored nets, are labor intensive, which limits the extent to which samples can be replicated in space and time.

For some invertebrates, particularly barnacles, Yund et al. (1991) solved the problems just outlined by using tube traps that passively collect larvae that fall into them. Unfortunately, the behavior of fish larvae appears to be too complex for them to be sampled adequately by these inexpensive, yet effective devices (Yund et al. 1991). Standardized units of artificial substrate suspended in the water column have successfully been used to collect settling larvae (or postlarvae) of a wide variety of invertebrates (e.g. Witham et al. 1968, Beninger et al. 1986, Peterson \& Summerson 1992, Ebert et al. 1994, Herrnkind \& Butler 1994, Eggleston \& Armstrong 1995). The rate of accumulation of recently settled decapods onto these collectors closely mirrors larval supply as estimated from samples concurrently collected in plankton nets (Lipcius et al. 1990, Herrnkind \& Butler 1994, Eggleston \& Armstrong 1995). Therefore, these devices can be used to measure patterns of larval delivery (Herrnkind \&
Butler 1994, Eggleston et al. 1998). In this paper, we describe a very similar device that allowed us to collect time-integrated samples of settlement-stage kelp bass (Paralabrax clathratus; family Serranidae) with relatively low cost and effort.

We use this new method to test whether the abundance of young kelp bass can be predicted from patterns of larval supply measured at a relatively large spatial scale $(10 \mathrm{~s}$ of $\mathrm{km})$. This test compares our index of larval supply (measured over nearly an entire settlement season) with the abundance of young-of-the-year (YOY) kelp bass, sampled after the end of the settlement season, at 4 sites spread over about $35 \mathrm{~km}$ of shoreline. We also test whether spatial patterns of larval supply are coherent over time at 2 scales.

\section{METHODS AND RESULTS}

We conducted this study from 1996 to 1998 at Santa Catalina Island $\left(33^{\circ} 27^{\prime} \mathrm{N}, 118^{\circ} 29^{\prime} \mathrm{W}\right), 35 \mathrm{~km}$ off the coast of southern California. Our focal species, the kelp bass, is one of the most abundant fish on rocky reefs in Southern California, USA, and northern Baja California, Mexico. This piscivore is among the most important inhabitants of subtidal reefs in this zone because of its effects on populations of other fishes (e.g. Steele 1997, 1998, Anderson 2001).

Variable recruitment of YOY may be an important cause of spatiotemporal variation in the abundance of kelp bass (Carr 1994). At the relatively small spatial scale of sites separated by $<10 \mathrm{~km}$, Carr (1994) found that recruitment of kelp bass was well predicted by the abundance of the canopy forming macroalga Macrocystis pyrifera (hereafter referred to as Macrocystis). Yet it is not known whether recruitment is as tightly linked to the abundance of Macrocystis at larger scales. It is also not known what, if any, role larval delivery plays in establishing patterns of recruitment. We explore these issues here.

Kelp bass larvae settle to benthic habitats (mainly macroalgae; Carr 1991) after about a month in the plankton at $9.5 \mathrm{~mm}$ mean standard length (SL) (McClean 1999). Movements after settlement are typically confined to redistribution within the large (1000s of $\mathrm{m}^{2}$ ), continuous, rocky reefs that they inhabit, and among-reef migrations are rare (Young 1963). Hence, the abundance of kelp bass on a reef is mainly set by the rate of settlement of larvae, and mortality of juveniles and adults on that reef. Settlement of kelp bass is seasonal, occurring from July to September at Santa Catalina (Carr 1994). Because settlement is seasonal and growth is relatively rapid, YOY, 1, and $2 \mathrm{yr}$ olds can be easily distinguished by size. One yr old fish average about $100 \mathrm{~mm}$ and 2 yr olds about $150 \mathrm{~mm}$ 
(Young 1963, Coyer 1979). Adults attain ages of $33 \mathrm{yr}$ and lengths of $600 \mathrm{~mm}$ (Love et al. 1996).

\section{A comparison of methods for estimating larval supply}

We tested 3 different methods for estimating larval supply of kelp bass: light traps, 'benthic collectors' composed of rocks placed inside plastic cages on the sandy bottom offshore of rocky reefs, and 'water column collectors' composed of artificial materials suspended in the water column. All 3 methods caught only kelp bass that were developmentally competent to settle (based on their pigmentation and size, 8 to $17 \mathrm{~mm}$ SL). The light traps used were essentially replicas of those used by Sponaugle \& Cowen (1996a). They used a $6 \mathrm{~W}$, fluorescent light that was powered by 4 rechargeable 'D-cell' alkaline batteries. The traps were lit during all hours of darkness and their contents were collected within a few hours of sunrise and later sorted in the lab. Each trap was moored to an anchored line over a sand bottom ( 7 to $14 \mathrm{~m}$ deep), $15 \mathrm{~m}$ offshore of rocky reefs, and the top of the trap was $5 \mathrm{~m}$ off the bottom. The entire process of gathering a sample of kelp bass larvae, from preparing the trap to be set out in the field to the finished product of a sample of larval fish sorted from the other contents of the trap, required about 1.5 person-h per sample.

Each benthic collector consisted of 22 natural rocks, each 15 to $30 \mathrm{~cm}$ in length (about $40 \mathrm{l}$ in volume) placed inside a cage, $0.9 \times 0.9 \times 0.6 \mathrm{~m}$ high, built of rigid plastic netting (mesh size $=19 \mathrm{~mm}$ ) on a PVC pipe frame $(2.5 \mathrm{~cm}$ outer diameter). These collectors were set $10 \mathrm{~m}$ off the nearby reefs on sand plains in 7 to $15 \mathrm{~m}$ of water. Divers harvested recently settled kelp bass from these collectors by removing the lid of the cage, squirting a solution (10\% in ethanol) of the anesthetic quinaldine into the interstices of the rocks, and then capturing with handnets any fish encountered while carefully removing each rock from the cage. It took about 30 person-min to gather a sample from a collector.

The water column collectors were built of a $1.2 \times$ $1.5 \mathrm{~m}$ sheet of barrier fencing material $(0.5 \mathrm{~mm}$ thick plastic with $32 \times 32 \mathrm{~mm}$ mesh), crumpled up and placed inside a plastic mesh $(13 \mathrm{~mm})$ bag. We used green fencing material, which was intended to mimic the complex, sheltered microhabitat provided by the macroalgae onto which kelp bass naturally settle. Each bag of fencing material was approximately $0.9 \mathrm{~m}$ long and $0.3 \mathrm{~m}$ in diameter, and each collector consisted of 2 bags that were suspended $5 \mathrm{~m}$ below the surface, attached to a buoyed polypropylene line. The collectors were placed $5 \mathrm{~m}$ deep because 2 earlier studies (Carr 1991, McClean 1999) found that similar devices captured more than twice as many settling kelp bass larvae at this depth than in the top meter of the water column or near the bottom. The water column collectors were placed 10 or $15 \mathrm{~m}$ (depending on the studysee below) off nearby reefs in water 7 to $30 \mathrm{~m}$ deep. In addition to containing the fencing material, the plastic mesh bags provided protection from predators, all of which are too large to pass through the mesh. Predation might otherwise obscure patterns of larval supply (e.g. Steele \& Forrester 2002). Initially, pouches of live algae were placed in some collectors in case chemical cues from the algae increased their attractiveness to kelp bass larvae; however, paired comparisons indicated only a slight and non-significant difference in catch rates between adjacent collectors with and without algae (McClean 1999), so we ceased adding algae. Divers harvested the water column collectors by carefully unclipping each bag from the buoyed line while making sure that their bubbles did not disturb the collector, and then surrounding each unit with a larger, $1 \mathrm{~mm}$ mesh bag, through which the small kelp bass could not pass. When approached by divers, recently settled bass hid within the collector, so few, if any, escaped. A new collector was attached to the buoyed line immediately after bagging the old one. The bagged collectors were placed in a large plastic barrel of seawater and brought back to the lab where each unit of the collector was vigorously shaken, in seawater, into the $1 \mathrm{~mm}$ mesh bag and all kelp bass were retrieved, counted, and measured. It took about 30 person-min to gather each collector, replace it with a new one, and process each sample.

We compared the efficacy of the 3 different methods for estimating larval supply of kelp bass in a $4 \mathrm{~d}$ long experiment done from September 2 to 5, 1996. We sampled each of the 3 different types of collector daily at 2 sites that were separated by about $200 \mathrm{~m}$ of sand bottom. Even though the 2 sites are very close to each other, they experience quite different regimes of water flow and delivery of zooplankton (Anderson \& Sabado 1995). At both sites, each of the 3 types of collectors was placed at 4 sampling stations, which were spaced $30 \mathrm{~m}$ apart and arrayed roughly in a line following the contour of the nearby rocky reefs. Benthic collectors were placed $10 \mathrm{~m}$ from the edge of the reef, whereas light traps and water column collectors were placed $15 \mathrm{~m}$ off the reef. At each station, the 3 types of collectors were spaced $5 \mathrm{~m}$ apart from one another.

We found that all 3 methods for estimating larval supply caught settlement stage kelp bass, but the water column collectors caught nearly 9 times more kelp bass than light traps and 5 times more kelp bass than benthic collectors. Water column collectors captured $1.41( \pm 0.32,1 \mathrm{SE} ; \mathrm{n}=8)$ kelp bass collector ${ }^{-1} \mathrm{~d}^{-1}$ versus $0.16( \pm 0.10 ; n=8)$ for light traps and $0.28( \pm 0.12$; 
$\mathrm{n}=8$ ) for benthic collectors. The differences in catch among collector types were statistically significant $\left(F_{2,12}=18.0, \mathrm{p}=0.0002\right)$ when tested by a 3-way ANOVA including the factors 'collector type', 'site', and 'station' nested within 'site', which compared the total number of larvae captured by each collector over the $4 \mathrm{~d}$ period (transformed to $\ln (x+1)$ to meet the assumption of homogeneity of variances). Post-hoc Tukey HSD tests revealed that the water column collectors caught significantly more larvae than the other 2 techniques $(p<0.002)$, but the catches from the other 2 techniques were indistinguishable $(p=0.69)$. There was no significant interaction between collector type and site $\left(F_{2,12}=2.9, \mathrm{p}=0.09\right)$, suggesting that the 3 methods measured the same spatial pattern of larval supply. However, the power of this test to detect differences of the magnitude observed was low $(48 \%$; calculated following Zar 1996).

\section{Testing a method for estimating larval supply that requires only weekly sampling}

Because the water column collectors caught so many more settlement stage kelp bass than the other 2 methods, we used them for the rest of the study. The next element of our work was to develop a more labor efficient method for estimating larval supply. In the study just described, we sampled larval supply daily, which was time consuming. In this portion of the study, we explored whether we could sample weekly instead of daily and still obtain adequate estimates of cumulative larval supply. For this experiment, we used paired collectors from which kelp bass were harvested daily from 1 member and weekly from the other. We installed 5 pairs of collectors at 2 sites and sampled them in 2 years at Ripper's Reef and 1 yr at Habitat Reef. Daily and weekly samples were harvested over 2 wk (i.e. 14 daily samples and 2 weekly samples per replicate pair of collectors) at Ripper's Reef in 1997, over 1 wk at Habitat Reef in 1997, and over 7 wk at Ripper's Reef in 1998. Paired collectors were $5 \mathrm{~m}$ apart and separated from adjacent pairs by $50 \mathrm{~m}$. All collectors were placed over sand bottoms, $10 \mathrm{~m}$ off the edge of the nearby natural reefs.

We evaluated the adequacy of weekly sampling by testing whether it recorded the same spatiotemporal patterns of larval supply as estimated by daily sampling. We compared the total number of kelp bass harvested from the 2 members of each pair of collectors over the duration of the sampling periods (1 to $7 \mathrm{wk}$ ) with 2 statistical techniques: ANOVA and linear regression. First, we tested for a significant interaction between 'treatment' (daily or weekly) and 'site/year' (Habitat 1997, Ripper's 1997, and Ripper's 1998) in a 3 -way ANOVA that included these 2 factors and the
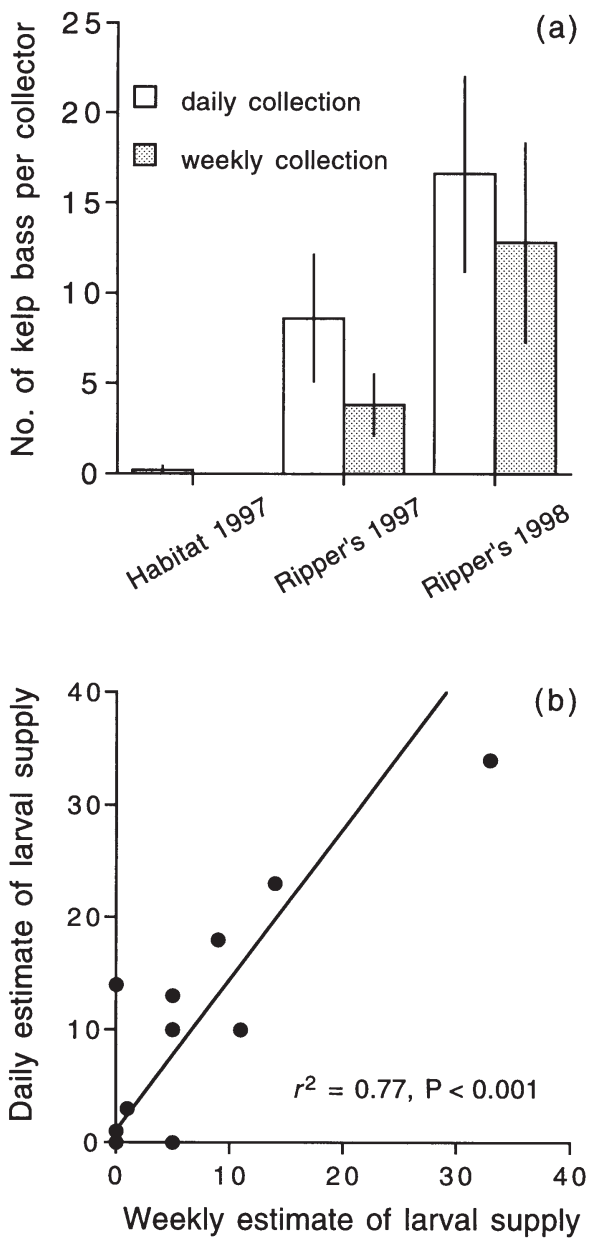

Fig. 1. Comparison of spatiotemporal patterns of larval supply estimated by daily versus weekly sampling of water column collectors. (a) Comparison of 3 different combinations of site and sampling period. The total number of kelp bass per collector is shown (mean $\pm 1 \mathrm{SE}, \mathrm{n}=5$ for each bar). Spatiotemporal patterns of larval supply did not differ significantly between the 2 measurement frequencies (see 'Methods and results'). (b) Data from all 3 site/period combinations pooled. Each point $(n=15)$ gives the total numbers of kelp bass collected from each member of a pair of collectors (1 sampled daily, the other weekly) at a sampling station

factor 'sampling station' nested within 'site/year.' There was no significant interaction between treatment and site/year (ANOVA, $F_{2,12}=0.25, \mathrm{p}=0.78$ ), suggesting that the among 'site/year' patterns of larval supply measured daily were not distorted by weekly sampling. Visual inspection of Fig. 1a suggests that this finding is robust even though the power of this test to detect differences as large as those observed was not high $(<30 \%)$. There tended to be fewer recently settled bass on collectors harvested weekly than on those harvested daily (Fig. 1a), but this trend was not statistically significant (ANOVA, $F_{1,12}=2.2, p=0.17$ ). However, the power of this test to detect a difference of the 

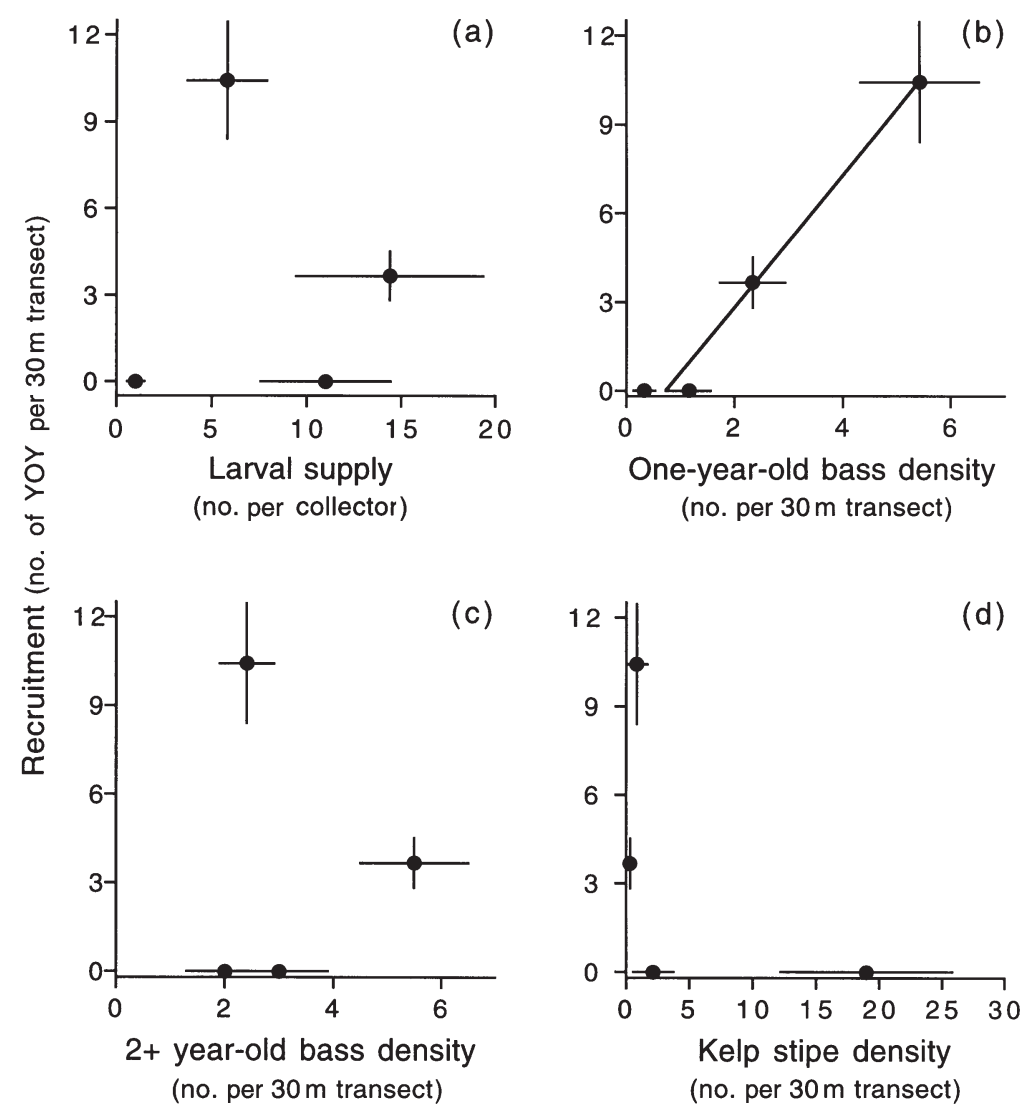

Fig. 2. Relationships between recruitment of YOY kelp bass and (a) larval supply (total number of just settled bass harvested over 9 wk per collector), (b) 1 yr old bass, (c) bass 2 yr old and older, and (d) the alga Macrocystis. Each point is a mean $\pm 1 \mathrm{SE}$ for a site and is based on $\mathrm{n}=5$ samples for larval supply and $\mathrm{n}=6$ for all other measures magnitude observed was $<30 \%$. With linear regression we tested whether the total catch of settled larvae from collectors harvested daily could be accurately predicted from the catch on paired collectors sampled weekly. For this analysis, we pooled the data from the 3 'site/year' combinations for a total of 15 data points. Larval supply, estimated by summing daily samples, was quite accurately predicted from weekly samples $\left(\mathrm{r}^{2}=0.77, \mathrm{p}<0.001\right.$; Fig. 1b).

\section{Does larval supply drive spatial patterns of recruitment?}

The preceding study demonstrated that weekly sampling of water column collectors provided a useful estimate of larval supply. We therefore used this technique in 1997 to estimate larval supply of kelp bass during the settlement season at 4 sites spread over about $35 \mathrm{~km}$ of the coastline of Santa Catalina Island to test whether variation in larval supply caused any observed differences in recruitment of YOY kelp bass among sites. Each site supported a resident population of kelp bass on a large (1000s of $\mathrm{m}^{2}$ ) rocky reef that was isolated from other nearby rocky reefs by at least several $10 \mathrm{~s}$ of $\mathrm{m}$ of bare sand bottom.

Larval supply at each site was estimated from 5 replicate water column collectors that were placed $10 \mathrm{~m}$ off the reef and spread evenly along $200 \mathrm{~m}$. Recently settled bass were collected weekly for 9 wk, from July 3 to September 3, a period that encompassed the vast majority of the settlement season for kelp bass at Santa Catalina Island (Carr 1994). We measured the density of YOY kelp bass with underwater visual censuses at each site in April 1998, about 6 mo after the end of the settlement season, when YOY bass were large enough to be easily counted by divers. During these censuses we also estimated the density of older kelp bass and the macroalga Macrocystis. We measured the density of older kelp bass to evaluate whether differences in bass density among sites were consistent among age classes. Such consistency might indicate that some deterministic process, or set of processes, was setting abundance at the sites. Kelp bass and Macrocystis were surveyed along six $30 \times 1 \times 2 \mathrm{~m}$ high band transects at each site following the methods of Carr (1994). Briefly, transects were surveyed at depths of 6 to $18 \mathrm{~m}$ on which divers recorded the numbers of kelp bass in 3 size categories: <100, 100 to 150, and $>150 \mathrm{~mm} \mathrm{SL}$, corresponding to YOY (<1 yr old), 1 yr olds, and 2 yr and older. Macrocystis abundance was estimated as the number of stipes present per transect.

Recruitment of YOY kelp bass was unrelated to larval supply at the 4 sites ( $r=-0.002, p=0.998$; Fig. 2a). The density of YOY kelp bass was, however, strongly positively correlated with density of 1 yr old bass $(r=0.99, p=0.01$; Fig. 2b), suggesting that spatial patterns of recruitment were consistent between these 2 year classes. However, YOY density was not correlated with the density of bass $2 \mathrm{yr}$ old and older (Fig. 2c; $r=-0.003, p=0.997$ ). In addition, the density of YOY bass was not related to the density of Macrocystis stipes at each site (Fig. $2 \mathrm{~d}_{i} \mathrm{r}=-0.52$, $\mathrm{p}=0.48$ ). But with only 4 points, none of these tests has great reliability. 


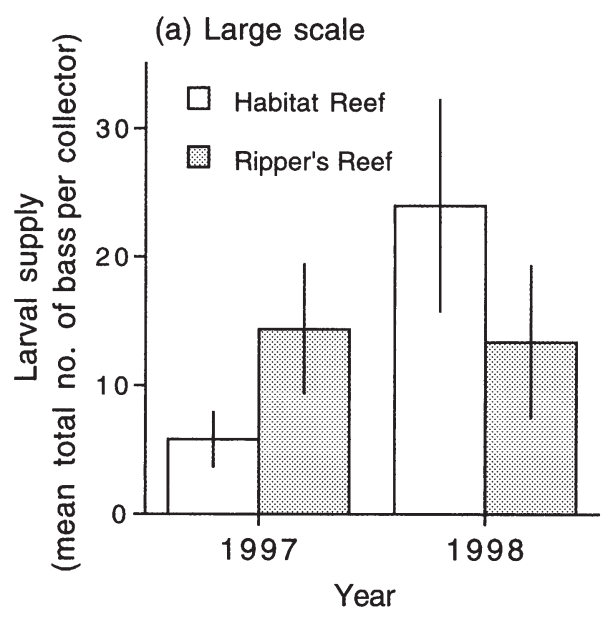

(b) Small scale

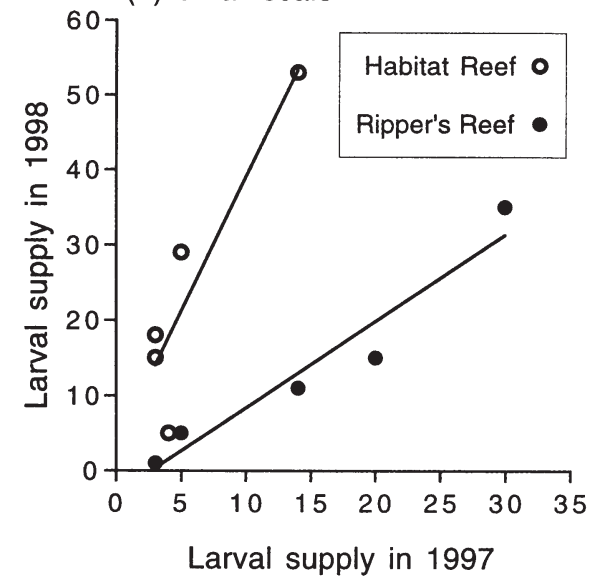

Fig. 3. Patterns of larval supply to 2 reefs in 2 yr at 2 spatial scales. (a) At the larger scale of sites separated by about $5 \mathrm{~km}$, the spatial pattern of larval supply differed significantly between the 2 yr (i.e. there was a significant 'site' by 'year' interaction in ANOVA - see 'Methods and results'). The total number of kelp bass harvested per collector over 9 wk in 1997 and $8 \mathrm{wk}$ in 1998 is shown. Each bar is the mean $( \pm 1 \mathrm{SE})$ of 5 collectors. (b) At the smaller scale of replicate sampling stations within sites ( $\mathrm{n}=5$ stations spread evenly along $200 \mathrm{~m}$ ), spatial patterns of larval supply were extremely similar between years, as indicated by strong correlations between the 2 years (see 'Methods and results')

\section{A test for temporal coherence in patterns of larval supply}

Using 2 sites from the preceding study (the loss of access to an adequate boat limited us to the 2 sites closest to our base of operations), we evaluated the coherence of spatial patterns in larval supply between 2 years at 2 spatial scales. We compared patterns in larval supply measured in 1997 with those measured in 1998 at Habitat Reef and Ripper's Reef. This comparison was made at the scale of sites that were separated by about $5 \mathrm{~km}$, and at the scale of replicate sampling stations within sites, which were separated by $50 \mathrm{~m}$. At each of 5 replicate sampling stations at the 2 sites, larval supply was estimated as the total of weekly catches of kelp bass from water column collectors. We sampled larval supply for 9 wk in 1997 (3 July to 3 September) and for 8 wk in 1998 (16 July to 10 September).

Patterns of larval supply were inconsistent between years at large scales but very consistent at small scales. Inconsistent patterns at the site scale were revealed by a significant interaction between the factors 'site' and 'year' $\left(F_{1,8}=22.3, \mathrm{p}=0.001\right.$; Fig. 3a) in a 3-way, nested ANOVA, with factors 'site', 'year', and 'sampling station,' which was nested within 'site'. (For this analysis, the number of larvae was transformed to $\ln (x+1)$ to homogenize variances.) By contrast, within sites, the spatial variation in larval supply was extremely consistent between years (Fig. 3b), as indicated by the tight correlations between the indices of larval supply from the 2 years at the 5 sampling stations at each site $(\mathrm{r}=0.91, \mathrm{p}=0.037$ and $\mathrm{r}=0.97, \mathrm{p}=0.008$ for Habitat Reef and Ripper's Reef, respectively).

\section{DISCUSSION}

Few studies (e.g. Yoshioka 1982, Bertness et al. 1992, Milicich et al. 1992, Sponaugle \& Cowen 1996b) have measured the influence of larval supply on population size because of the logistical difficulties involved in adequately sampling larvae. Our water column collectors offer a promising approach for measuring larval supply in reef fishes, an approach also applicable to marine invertebrates (e.g. Peterson \& Summerson 1992, Herrnkind \& Butler 1994, Eggleston et al. 1998), and one that offers a number of advantages over many other methods. Foremost among the advantages of our collectors is that they integrate larval supply over time and can be left untended for up to a week while still providing accurate estimates. In this regard, they resemble the tube collectors that Yund et al. (1991) developed to measure larval supply of barnacles. Further, all of the kelp bass harvested from our collectors were competent to settle, which allows us to rule out the possibility that the mismatch between recruitment and larval supply was caused by a biased index of larval supply that included some unknown fraction of individuals that were not yet ready to settle-a particular problem for studies using nets (Choat et al. 1993, Levin 1996). Additionally, our water column collectors caught more kelp bass per collector than the other 2 methods we tried. Although the relative capture rate of different techniques should not be the sole criterion used to choose a sampling method, it is an important consideration because methods that catch few larvae 
may have little ability to resolve spatiotemporal patterns of larval supply. Finally, our water column collectors were very inexpensive, required minimal effort to construct and required little effort to install and harvest. While it may not be possible to adapt our water column collectors for use with all or even the majority of reef fishes, with some ingenuity it should be possible to develop similar devices to measure larval supply of many species. For example, Behrents (1987) suspended buoys with holes drilled in them just above the seafloor, to which the goby Lythrypnus dalli settled; Levin (1996) suspended mop heads in the water column to collect settling larvae of the wrasse Tautogolabrus adspersus; D. Eggleston (pers. comm.) suspended air conditioner filter pads just beneath the surface (described in Eggleston et al. 1998) to collect settling larvae of the grouper Epinephelus striatus; and A. Ammann and J. Caselle (pers. comm.) have used devices nearly identical to ours to collect settling larvae of a number of rockfishes.

A number of factors may bias estimates of larval supply obtained from our water column collectors and similar devices, but several lines of evidence suggest that such biases may not be severe. Variation in factors such as current velocity, turbidity, lunar phase, and large-scale settlement cues could cause settlement onto water column collectors to fail to mirror true patterns of larval supply if such variation causes larvae settle onto collectors out of proportion to their abundance in the water column. In the present study, variation in turbidity did not seem to influence our estimates of larval supply, since high catches were made during high and low turbidity conditions. In addition, current had no significant influence on catches of kelp bass obtained from water column collectors (McClean 1999). Moreover, studies on other taxa that have compared catches of newly settled individuals on artificial substrates suspended in the water column with catches of settlement competent stages from moored plankton nets have found the 2 measures to be tightly correlated (Lipcius et al. 1990, Herrnkind \& Butler 1994, Eggleston \& Armstrong 1995, Eggleston et al. 1998, Eggleston unpubl. data). These studies encompassed a wide range of conditions (i.e. variable current speed, turbidity, lunar phase) and used a wide variety of taxa ( 2 crabs, a lobster, and a reef fish); thus they provide strong evidence that settlement onto artificial collectors can provide an unbiased estimate of larval supply.

\section{Are spatial patterns of larval supply consistent over time?}

Our study indicates that spatial patterns of larval supply of kelp bass were very consistent between 2 years at a relatively small scale of areas spread over $200 \mathrm{~m}$ but inconsistent at a larger scale of several $\mathrm{km}$. This finding suggests that it may be profitable to search for deterministic mechanisms that can drive patterns of larval supply at small scales. However, across taxa, no obvious scale at which patterns of larval supply are consistent has yet emerged. Studies done at the $\mathrm{km}$ scale have found both consistent (e.g. Sponaugle \& Cowen 1996a,b) and inconsistent (Milicich \& Doherty 1994, Bertness et al. 1996) patterns; and at smaller scales of a few to $10 \mathrm{~s}$ of $\mathrm{m}$, consistent (Jeffery \& Underwood 2000) and inconsistent (Gaines et al. 1985) patterns have also been found.

\section{What sets patterns of abundance in kelp bass?}

Here, we evaluated the role of larval supply in driving recruitment at a relatively large scale and with greater continuity of sampling than has typically been achieved in studies on fishes (e.g. Milicich et al. 1992, Levin 1996, Sponaugle \& Cowen 1996a,b, Jenkins et al. 1998). Our finding that the supply of settling larvae did not set spatial differences in recruitment among 4 sites is consistent with other studies on fish (e.g. Levin 1996, Sponaugle \& Cowen 1996b, Jenkins et al. 1998) and highly mobile invertebrates (e.g. Herrnkind \& Butler 1994, Eggleston \& Armstrong 1995), but contrasts with studies on less mobile and sessile invertebrates (e.g. Grosberg 1982, Gaines et al. 1985, Yund et al. 1991, Bertness et al. 1992, Peterson \& Summerson 1992, Gaines \& Bertness 1993). In kelp bass, something other than larval supply apparently set recruitment at our study sites. Earlier work by Carr (1994) showed the abundance of the kelp Macrocystis pyrifera to be an excellent predictor of kelp bass recruitment at the smaller scales he studied, but during our study, recruitment was unrelated to the abundance of this kelp. This result may be a consequence of the paucity of Macrocystis during the present study (it was more than 1 order of magnitude more common during Carr's study). During our study, however, recruitment was tightly positively correlated with the abundance of $1 \mathrm{yr}$ old kelp bass. Recruitment facilitation (e.g. Sweatman 1985) by 1 yr olds could have caused this correlation, but we believe this is unlikely because kelp bass are cannibals (Carr 1991) and recruitment was not related to the density of all older bass combined. The likely cause of the correlation between the 2 age classes is that the factors determining recruitment success in one year were the same in the next. The lack of a correlation between recruitment and the density of bass $2 \mathrm{yr}$ and older, however, suggests either that determinants of recruitment were not consistent among all years, or postsettlement processes acting after age 1 altered pat- 
terns of abundance from those set at recruitment. To understand more thoroughly the roles of larval supply, settlement, and postsettlement processes in driving spatial patterns and dynamics of marine populations, we need to expand our toolbox of techniques for measuring these processes. The simple technique for measuring larval supply described here is one such tool that may facilitate adequate replication across a range of scales and lead to a deeper understanding of how marine populations are regulated.

Acknowledgements. For able field assistance we thank S. Anderson, D. Conlin, P. Dixon, K. Flanagan, B. Fredericks, S. Grunwald, B. Hajduczek, J. Hooykaas, M. Phillips, R. Sahaghian, J. Schinske, H. Sheene, Y. Springer, C. Tinus, T. Trejo, K. Wisenbaker, and C. Yonker. Stimulating discussions with L. Allen, T. Anderson, and M. Hixon improved the study; comments from C. Peterson and 4 anonymous reviewers improved the manuscript. The staff of the Wrigley Institute for Environmental Studies (WIES) provided excellent logistical support. Financial support came from a grant from the National Science Foundation to G.F. (OCE 9618011/0096061); a traineeship from the UC Coastal Toxicology program to M.S.; and a graduate internship from WIES, funding from the Nearshore Marine Fish Research Program at CSU Northridge, and a grant from the Student Projects Committee at CSU Northridge to A.F. This is contribution number 216 from WIES.

\section{LITERATURE CITED}

Anderson TW (2001) Predator responses, prey refuges, and density-dependent mortality of a marine fish. Ecology 82: 245-257

Anderson TW, Sabado BD (1995) Correspondence between food availability and growth of a planktivorous temperate reef fish. J Exp Mar Biol Ecol 189:65-76

Behrents KC (1987) The influence of shelter availability on recruitment and early juvenile survivorship of Lythrypnus dalli Gilbert (Pisces: Gobiidae). J Exp Mar Biol Ecol 107: 45-59

Beninger PG, Chiasson L, Elner RW (1986) The utility of artificial collectors as a technique to study benthic settlement and early juvenile growth of the rock crab Cancer irroratus. Fish Res 4:317-329

Bertness MD, Gaines SD, Stephens EG, Yund PO (1992) Components of recruitment in populations of the acorn barnacle Semibalanus balanoides (Linnaeus). J Exp Mar Biol Ecol 156:199-215

Bertness MD, Gaines SD, Wahle RA (1996) Wind-driven settlement patterns in the acorn barnacle Semibalanus balanoides. Mar Ecol Prog Ser 137:103-110

Caley MJ, Carr MH, Hixon MA, Hughes TP, Jones GP, Menge BA (1996) Recruitment and the population dynamics of open marine populations. Annu Rev Ecol Syst 27:477-500

Carr MH (1991) Patterns, mechanisms, and consequences of recruitment of a temperate marine reef fish. PhD dissertation, University of California, Santa Barbara

Carr MH (1994) Effects of macroalgal dynamics on recruitment of a temperate reef fish. Ecology 75:1320-1333

Choat JH, Doherty PJ, Kerrigan BA, Leis JM (1993) A comparison of towed nets, purse seine, and light-aggregation devices for sampling larvae and pelagic juveniles of coral reef fishes. Fish Bull 91:195-209

Coyer JA (1979) The invertebrate assemblage associated with Macrocystis pyrifera and its utilization as a food source by kelp forest fishes. PhD dissertation, University of Southern California, Los Angeles

Doherty PJ, Kingsford M, Booth D, Carleton J (1996) Habitat selection before settlement by Pomacentrus coelestis. Mar Freshw Res 47:391-399

Ebert TA, Schroeter SC, Dixon JD, Kavass P (1994) Settlement patterns of red and purple urchins (Strongylocentrotus franciscanus and $S$. purpuratus) in California, USA. Mar Ecol Prog Ser 111:41-52

Eggleston DB, Armstrong DA (1995) Pre- and post-settlement determinants of estuarine Dungeness crab recruitment. Ecol Monogr 65:193-216

Eggleston DB, Lipcius RN, Marshall LS, Ratchford SG (1998) Spatiotemporal variation in postlarval recruitment of the Caribbean spiny lobster in the central Bahamas: lunar and seasonal periodicity, spatial coherence, and wind forcing. Mar Ecol Prog Ser 174:33-49

Gaines SD, Bertness M (1993) The dynamics of juvenile dispersal: why field ecologists must integrate. Ecology 74 : $2430-2435$

Gaines S, Brown S, Roughgarden J (1985) Spatial variation in larval concentrations as a cause of spatial variation in settlement for the barnacle, Balanus glandula. Oecologia 67: 267-272

Grosberg RK (1982) Intertidal zonation of barnacles: the influence of planktonic zonation of larvae on vertical distribution of adults. Ecology 63:894-899

Hamer PA, Jenkins GP (1996) Larval supply and short-term recruitment of a temperate zone demersal fish, the King George whiting, Sillaginodes punctata Cuvier and Valenciannés, to an embayment in south-eastern Australia. J Exp Mar Biol Ecol 208:197-214

Herrnkind WF, Butler MJ (1994) Settlement of spiny lobster, Panulirus argus (Latreille, 1804), in Florida: pattern without predictability? Crustaceana 67:46-64

Jeffery CJ, Underwood AJ (2000) Consistent spatial patterns of arrival of larvae of the honeycomb barnacle Chamaesipho tasmanica Foster and Anderson in New South Wales. J Exp Mar Biol Ecol 252:109-127

Jenkins GP, Keough MJ, Hamer PA (1998) The contributions of habitat structure and larval supply to broad-scale recruitment variability in a temperate zone, seagrassassociated fish. J Exp Mar Biol Ecol 226:259-278

Kaufman L, Ebersole J, Beets J, McIvor CC (1992) A key phase in the recruitment dynamics of coral reef fishes: post-settlement transition. Environ Biol Fish 34:109-118

Keener P, Johnson GD, Stender BW, Brothers EB, Beatty HR (1988) Ingress of postlarval gag, Mycteroperca microlepis (Pisces: Serranidae), through a South Carolina barrier island inlet. Bull Mar Sci 42:376-396

Leis JM, Carson-Ewart BM (1998) Complex behaviour by coral-reef fish larvae in open-water and near-reef pelagic environments. Environ Biol Fish 53:259-266

Levin PS (1996) Recruitment in a temperate demersal fish: Does larval supply matter? Limnol Oceanogr 41:672-679

Lipcius RN, Olmi EJ, van Montfans J (1990) Planktonic availability, molt stage and settlement of blue crab postlarvae. Mar Ecol Prog Ser 58:235-242

Love MS, Brooks A, Busatto D, Stephens J, Gregory PA (1996) Aspects of the life histories of the kelp bass, Paralabrax clathratus, and barred sand bass, $P$. nebulifer, from the southern California Bight. Fish Bull 94:472-481

McClean AM (1999) Settlement patterns of a temperate reef 
fish, Paralabrax clathratus, at Santa Catalina Island, CA. MSc thesis, California State University, Northridge

Milicich MJ, Doherty PJ (1994) Larval supply of coral reef fish populations: Magnitude and synchrony of replenishment to Lizard Island, Great Barrier Reef. Mar Ecol Prog Ser 110:121-134

Milicich MJ, Meekan MG, Doherty PJ (1992) Larval supply: a good predictor of recruitment in three species of reef fish (Pomacentridae). Mar Ecol Prog Ser 86:153-166

Olafsson EB, Peterson CH, Ambrose WGJ (1994) Does recruitment limitation structure populations and communities of macro-invertebrates in marine soft sediments: the relative significance of pre- and post-settlement processes. Oceanogr Mar Biol Annu Rev 32:65-109

Peterson CH, Summerson HC (1992) Basin-scale coherence of population dynamics of an exploited marine invertebrate, the bay scallop: Implications of recruitment limitation. Mar Ecol Prog Ser 90:257-272

Shenker JM, Maddox ED, Wishinski E, Pearl A, Thorrold SR, Smith N (1993) Onshore transport of settlement-stage Nassau grouper (Epinephelus striatus) and other fishes in Exuma Sound, Bahamas. Mar Ecol Prog Ser 98:31-43

Sponaugle S, Cowen RK (1996a) Nearshore patterns of coral reef fish larval supply to Barbados, West Indies. Mar Ecol Prog Ser 133:13-28

Sponaugle S, Cowen RK (1996b) Larval supply and patterns

Editorial responsibility: Charles Peterson (Contributing

Editor), Morehead City, North Carolina, USA of recruitment for two Caribbean reef fishes, Stegastes partitus and Acanthurus bahianus. Mar Freshw Res 47: 433-447

Steele MA (1997) The relative importance of processes affecting recruitment of two temperate reef fishes. Ecology 78 : 129-145

Steele MA (1998) The relative importance of predation and competition in two reef fishes. Oecologia 115:222-232

Steele MA, Forrester GE (2002) Early post-settlement predation on three reef fishes: effects on spatial patterns of recruitment. Ecology 83:1076-1091

Sweatman HPA (1985) The influence of adults of some coral reef fishes on larval recruitment. Ecol Monogr 55:469-485

Witham R, Ingle RM, Joyce EA (1968) Physiological and ecological studies of Panulirus argus from the St. Lucie estuary. Florida State Board of Conservation Technical Series No. 53

Yoshioka PM (1982) Role of planktonic and benthic factors in the population dynamics of the bryozoan Membranipora membranacea. Ecology 63:457-468

Young P (1963) The kelp bass (Paralabrax clathratus) and its fishery, 1947-1958. Calif Dep Fish Game Fish Bull 122: $1-67$

Yund PO, Gaines SD, Bertness MD (1991) Cylindrical tube traps for larval sampling. Limnol Oceanogr 36:1167-1177

Zar JH (1996) Biostatistical analysis. Prentice-Hall, New York

Submitted: November 29, 2000; Accepted: November 26, 2001 Proofs received from author(s): May 5, 2002 